CZASOPISMO INŻYNIERII LĄDOWEJ, ŚRODOWISKA I ARCHITEKTURY JOURNAL OF CIVIL ENGINEERING, ENVIRONMENT AND ARCHITECTURE JCEEA, t. XXXIII, z. 63 (4/16), październik-grudzień 2016, s. 339-346

\author{
Adam MROZIŃSKI ${ }^{1}$
}

\title{
LABORATORYJNA INSTALACJA FOTOWOLTAICZNA Z MAGAZYNEM ENERGII
}

\begin{abstract}
W artykule przedstawiono zagadnienie wykorzystania w Polsce i w Europie instalacji fotowoltaicznych (PV) z magazynami energii elektrycznej. Systemy PV będą miały w niedalekiej przyszłości znaczny udział w globalnej produkcji energii elektrycznej. Będzie to istotnie wpływało na ograniczenie emisji gazów cieplarnianych oraz na poprawę stanu środowiska naturalnego. W pracy przedstawiono budowę laboratoryjnej instalacji PV zlokalizowanej na WIM UTP w Bydgoszczy. Przedstawiono również wybrane wyniki pomiarów rozkładu produkcji i dystrybucji energii elektrycznej w czasie (produkcja przez układ PV, zużycie własne, magazynowanie w akum, przesył do sieci zewn.) z wykorzystaniem systemu monitoringu. W instalacjach PV coraz większe znaczenie mają systemy zarządzania energią oraz układy magazynujące energię elektryczną. Dzięki tym systemom energia elektryczna produkowana w ciągu dnia będzie zużywana na bieżąco. Nadmiar energii trafi do przydomowego akumulatora. Zgromadzona energia efektywnie zostanie wykorzystana wieczorem, kiedy zapotrzebowanie na prąd jest najwyższe. Ewentualne niedobory pokryje energia z sieci - kupiona nocą lub wczesnym rankiem, kiedy cena energii jest najniższa. Inteligentne sieci przesyłowe współpracujące z przydomowymi instalacjami PV z magazynami energii umożliwią skuteczniejsze zarządzanie popytem i podażą energii w całym systemie energetycznym.
\end{abstract}

Słowa kluczowe: OZE, efektywność, fotowoltaika, magazyny energii

\section{Czy magazynowanie energii elektrycznej zmieni rynek PV?}

Na rynku przydomowych instalacji fotowoltaicznych (PV) zaczyna zauważać się zjawisko powstawania instalacji PV dedykowanych dla osób, które chcą w całości lub w znacznej mierze zużywać produkowaną energię na własne potrzeby. Do tej pory tak działające instalacje były skomplikowane i wymagały kilku urządzeń, a także bardzo często nie mogły być przyłączone do sieci lokalnego operatora elektroenergetycznego, a co za tym idzie wymagały dedykowanego obwodu, który miały zasilać [2, 3, 4].

\footnotetext{
${ }^{1}$ Adam Mroziński, Uniwersytet Technologiczno-Przyrodniczy w Bydgoszczy, Wydział Inżynierii Mechanicznej, 85-796 Bydgoszcz, Al. Prof. S. Kaliskiego 7, tel.: 5234084 53, adammroz@utp.edu.pl, www.amrozinski.utp.edu.pl, www.oze.utp.edu.pl
} 
Drugą wadą była trwałość akumulatorów, która w zależności od wybranej technologii gwarantowała ich pracę jedynie od 3 do 7 lat. Trzecim problemem była spadająca w czasie pojemność akumulatorów oraz konieczność utrzymania ich stanu naładowania na odpowiednim poziomie [1,2].

Wszystkie powyższe problemy rozwiązują systemy, którego praktyczny przykład przedstawiono w niniejszym artykule. Analizowana instalacja gromadzi nadwyżki energii elektrycznej, która jest produkowana przez instalacje fotowoltaiczną. Zagadnienie to przedstawiono na rys. 1. Przedstawiono na nim dobowy rozkład zużycia energii w obiekcie, produkcji energii przez instalację PV, wartość energii dostarczanej do sieci, wartość energii pobieranej z sieci oraz najważniejszy element $\mathrm{w}$ postaci poziomu energii pochodzącej $\mathrm{z}$ magazynu energii. Jak widać możliwe jest teoretycznie uzyskanie wariantu np. 8\% udziału zasilania z sieci. Udział ten będzie oczywiście uzależniony od wielkości instalacji PV oraz od pojemności zastosowanego magazynu energii elektrycznej $[7,8]$.

Zgromadzone nadwyżki są wykorzystywane w momencie, kiedy wzrasta pobór energii, lub kiedy instalacja fotowoltaiczna nie produkuje energii elektrycznej. W przypadku, kiedy wystąpi awaria sieci elektroenergetycznej, sieć domowa zostaje odłączona poprzez urządzenie sterujące. Dzięki takiemu rozwiązaniu, jeżeli posiadamy naładowaną baterię lub instalacja fotowoltaiczna pracuje, dom może być dalej zasilany przez energię elektryczną. W przypadku instalacji z magazynowaniem energii całą energię (lub spora jej część), którą wyprodukujemy - zużyjemy. Mimo wyższych nakładów inwestycyjnych niż przy instalacji typu on grid, zwrot poniesionych kosztów może być zdecydowanie krótszy, dzięki wykorzystywaniu 100\% produkowanej energii na swoje potrzeby. Dla użytkownika takiej instalacji oznacza to, że rachunki za energię elektryczną będą bliskie zeru. Takie rozwiązanie uniezależnia użytkowników od dostawcy energii elektrycznej oraz daje gwarancję, że nawet w przypadku awarii sieci zasilanie obiektu mieszkalnego będzie podtrzymywane.

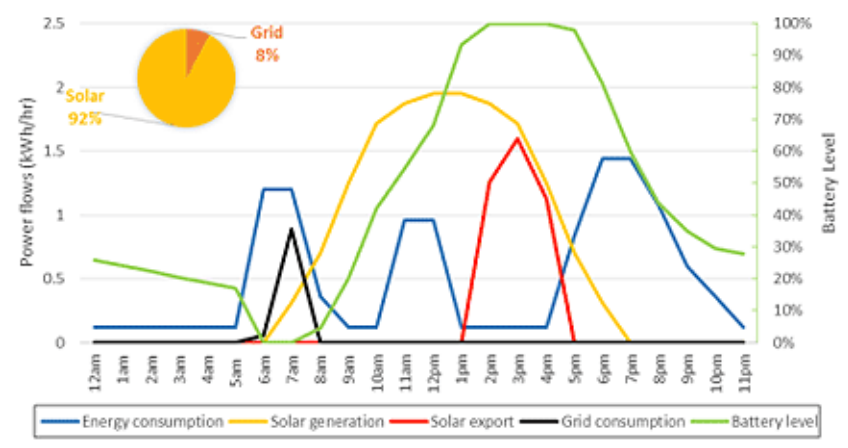

Rys. 1. Schemat popytu i podaży prądu w gospodarstwie domowym wyposażonym w system produkcji i magazynowania energii, na podstawie [8]

Fig. 1. Scheme of demand and supply of electric energy in household equipped on production and storing system, based on [8] 
Tego typu rozwiązanie wymaga istotnego założenia ekonomicznego. Należy oczywiście założyć, że koszt magazynów energii będzie spadać. Czy to założenie jest dyskusyjne? Panele słoneczne kosztują obecnie $80 \%$ mniej niż pięć lat temu. To samo prawdopodobnie stanie się z akumulatorami do magazynowania energii elektrycznej. A wtedy rynek zmieni się diametralnie. Gdyby założenia te się sprawdziły, powstanie wielu prywatnych magazynów energii w Europie miałoby kolosalny wpływ na wielkich operatorów energetycznych. Mogłoby się okazać, iż klientami tradycyjnych elektrowni zostałyby tylko duże przedsiębiorstwa, a odbiorcy indywidualni staliby się samowystarczalni.

\section{Magazynowanie energii - technologiczne wyzwania}

$\mathrm{Na}$ rynku magazynowania energii elektrycznej zaczynają dominować dziś akumulatory litowo-jonowe, ogniwa oparte o prosty i wydajny mechanizm elektrochemiczny. Nie trzeba ich rozładowywać do końca, co było wadą poprzedniej generacji akumulatorów niklowych. Akumulatory te dobrze znoszą szybkie ładowanie. Są one chwilowo bezkonkurencyjne jeśli chodzi o gęstość gromadzonej energii (2,5-5 razy więcej na jednostkę masy niż akumulator kwasowoołowiowy) i wykazują jeszcze spory potencjał rozwojowy. Zdolność do gromadzenia energii wybranych technologii przedstawiono na rysunku 2. Przykładem dynamicznego rozwoju rynku niech będzie oferta cenowa firmy Tesla w zakresie domowych magazynów energii (rys. 3).

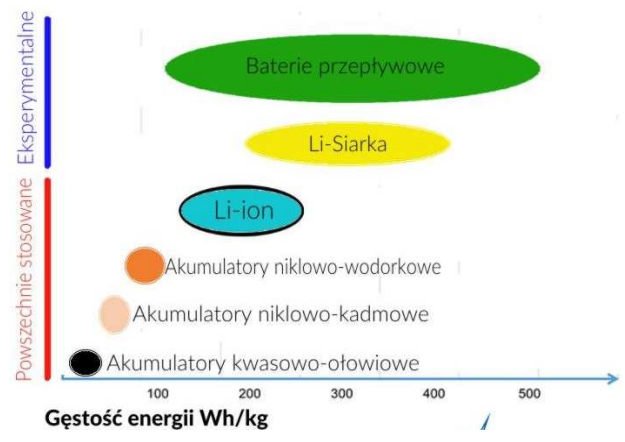

Rys. 2. Zdolność gromadzenia energii wybranych technologii baterii, na podstawie [2, 3, 4]

Fig. 2. Ability of energy accumulating of choose technology of battery, based on $[2,3,4]$

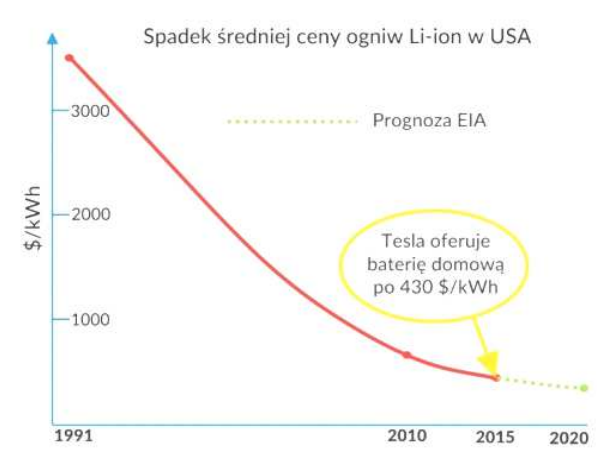

Rys. 3. Spadek średniej ceny ogniw Li-ion w USA, na podstawie [7, 8]

Fig. 3. Fall of average price of Li-ion cells in USA, based on $[7,8]$

Warto sobie zdawać sprawę, że większe systemy magazynowania energii, nawet o pojemności rzędu 1 MWh i megawatowej mocy są już komercyjnie dostępne, także z przeznaczeniem dla lokalnych, izolowanych sieci energetycznych opartych o OZE. Takie "wielkomocowe" układy będą musiały być budowane w miarę rozwoju energetyki odnawialnej w Europie $[5,6]$. 
Sukces technologii litowo-jonowej, wynikający m.in. z głównie z komercyjnego rozwoju rynku motoryzacyjnego firmy Tesla, ma oczywiście swoje ograniczenia. Baterie tego typu przez ostatnie 20 lat staniały znacząco, ale tempo spadku cen ostatnio wyhamowało [8]. W miarę rozwoju technologii produkcji decydującą rolę $w$ cenie zacznie prawdopodobnie odgrywać znaczny udział surowców, a zwłaszcza samego litu. Metal ten jest bardzo rozpowszechniony, ale jednocześnie rozproszony i nadające się do eksploatacji złoża nie są zbyt wielkie. W dodatku ponad połowa zasobów jest skoncentrowanych na dnie wyschniętych słonych jezior na pograniczu Argentyny, Boliwii i Chile. Spadek kosztów wytwarzania może więc zostać zniweczony przez wzrost cen. Zwłaszcza, że potencjalnie znacznie lepsza bateria - litowo-siarczkowa także będzie oparta na tym pierwiastku $[6,8,10]$.

\section{Budowa laboratoryjnej instalacji fotowoltaicznej z magazynem energii}

Laboratoryjną instalację fotowoltaiczną, funkcjonującą na budynku Wydziału Inżynierii Mechanicznej UTP w Bydgoszczy przedstawiono na rysunku 4. W instalacji zastosowano monokrystaliczne moduły fotowoltaiczne o mocy całkowitej $5000 \mathrm{~W}_{\mathrm{p}}$. Zamocowano je na dachu budynku hali technologicznej WIMUTP pod kątem 20 stopni.

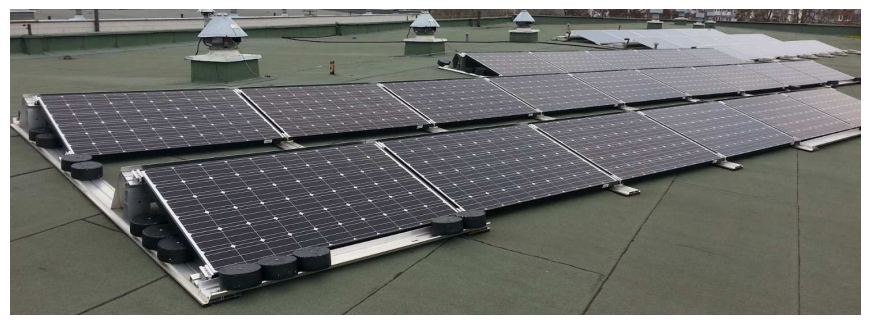

Rys. 4. Instalacja fotowoltaiczna na WIM UTP w Bydgoszczy [9]

Fig. 4. Photovoltaic installation on the WIM UTP in Bydgoszcz [9]

W instalacji wykorzystano system Fronius Symo Hybrid 5.0-3-S. Trójfazowy hybrydowy falownik o mocy $5,0 \mathrm{~kW}$ umożliwia gromadzenie w akumulatorze nadmiaru energii wygenerowanej przez instalację fotowoltaiczną. Tego typu układ charakteryzuje się maksymalnym udziałem zużycia energii na potrzeby własne i maksymalną niezależnością od zewnętrznych dostaw energii.

W ten sposób nadmiar energii solarnej można wykorzystać w okresach, gdy tej energii jest mało lub też, gdy w ogóle nie jest wytwarzana. Dzięki funkcji zasilania awaryjnego gospodarstwo domowe może być optymalnie zasilane energią także w przypadku przerw w dostawie energii. Konfiguracja i wizualizacja instalacji jest możliwa za pośrednictwem zintegrowanego serwera www 
z interfejsem graficznym, zarówno przez WLAN, jak i Ethernet. Ładowanie akumulatora bezpośrednio od strony DC instalacji PV (ang. DC-coupling) zapewnia także maksymalny współczynnik sprawności całej instalacji.

Do magazynowania energii elektrycznej w analizowanej instalacji wykorzystywany był system Fronius Solar Battery. Magazyn energii Fronius Solar Battery to wydajna technologia litowo-żelazowo-fosforanową, która gwarantuje długą żywotność, krótkie czasy ładowania i dużą głębokość rozładowania. Pojemność tego magazynu energii można dostosować do indywidualnych potrzeb obiektu, a także zwiększać w późniejszym czasie. Zakres pojemności baterii akumulatorów wynosi od 4,5 do 12kWh (rys. 5).

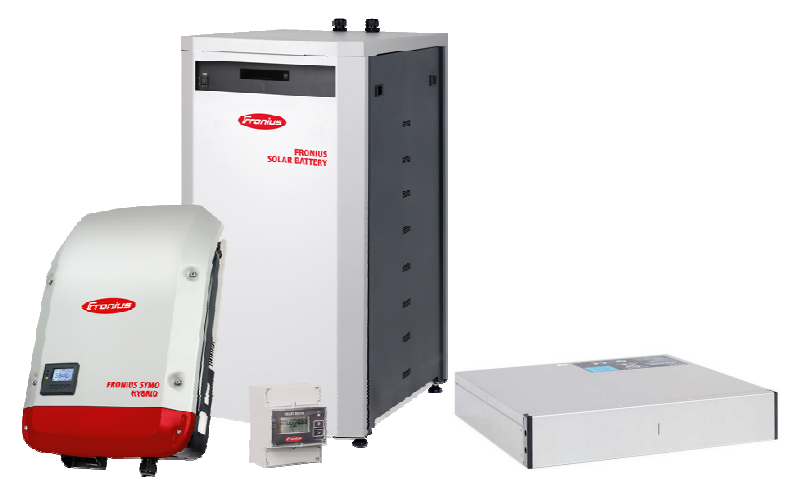

Rys. 5. Fronius Symo Hybrid 5.0-3-S S24, Fronius Smart Meter oraz Fronius Solar Battery, na podstawie $[6,7]$

Fig. 5. Fronius Symo Hybrid 5.0-3-S S24, Fronius Smart Meter and Fronius Solar Battery, based on [6, 7]

Założono, że przy prawidłowo dobranej mocy generatora fotowoltaicznego można uzyskać pełną niezależność energetyczną budynku 1-rodzinnego. Podczas realizowanych badań symulowano właśnie tego typu układ energetyczny. Statystycznie jedna osoba w gospodarstwie domowym zużywa $2 \mathrm{kWh}$ energii na

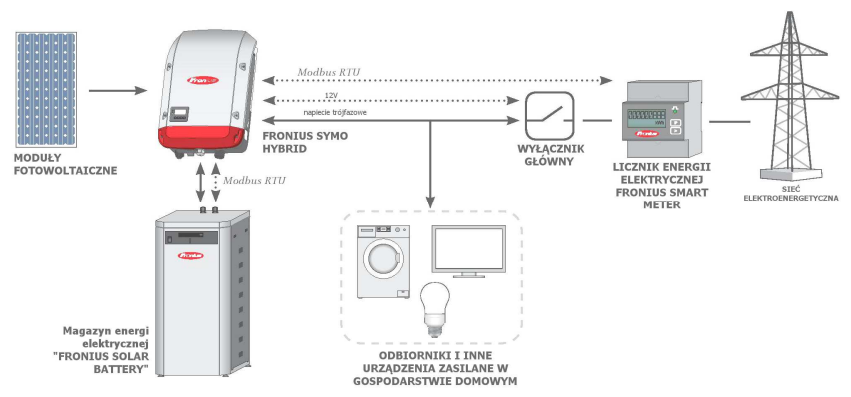

Rys. 6. Schemat instalacji z magazynem energii, na podstawie $[6,7]$

Fig. 6. Scheme of installation with energy storage, based on $[6,7]$ 
dobę. Bateria akumulatorów pozwala na pracę bez zasilania z zewnątrz przez 24 godziny/dobę. System uzupełniany jest również o tzw. Fronius Smart Meter czyli dwukierunkowy licznik służący do optymalizacji zużycia własnego i rejestracji krzywej obciążenia gospodarstwa domowego. W połączeniu z portalem online Fronius Solar.web Fronius Smart Meter umożliwia przejrzystą prezentację własnego zużycia energii elektrycznej (rys. 6).

\section{Monitoring parametrów instalacji fotowoltaicznej}

Systemy monitoringu są obecnie nieodłącznym elementem instalacji fotowoltaicznych. Pomagają utrzymać maksymalną wydajność systemu oraz wskazywać ewentualne usterki już na początkowym etapie działania instalacji. Dzięki temu można uniknąć przestojów w produkcji energii elektrycznej. Obecnie dla inwestora nie są istotne tylko sumaryczne dane energetyczne całego systemu, ale również dane chwilowe i bardziej szczegółowe - np. parametry stringów modułów PV (wydzielone ciągi modułów).

Na rysunku 7 i 8 przedstawiono wybrane wyniki pomiarów rozkładu produkcji i dystrybucji energii elektrycznej (produkcja przez układ PV, zużycie własne, magazynowanie w akumulatorach, przesył do sieci zewnętrznej) w czasie z wykorzystaniem systemu monitoringu.

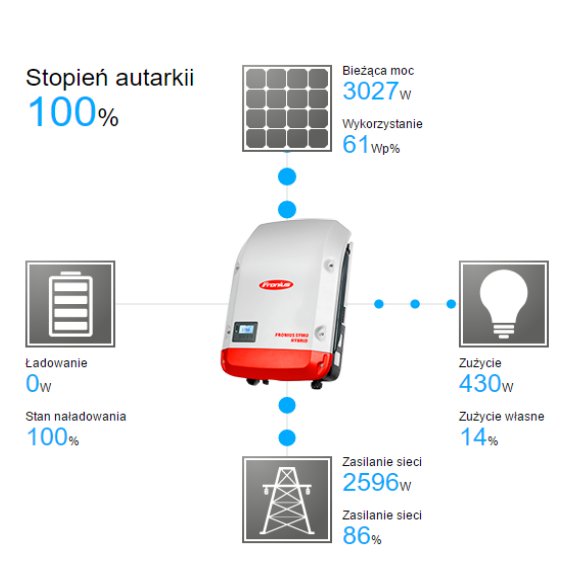

Rys. 7. Wykorzystany w instalacji PV system monitorowania - przykładowe wyniki pomiarów, na podstawie $[6,9]$

Fig. 7. System of monitoring used in PV installation - results examples of measurements, based on $[6,9]$

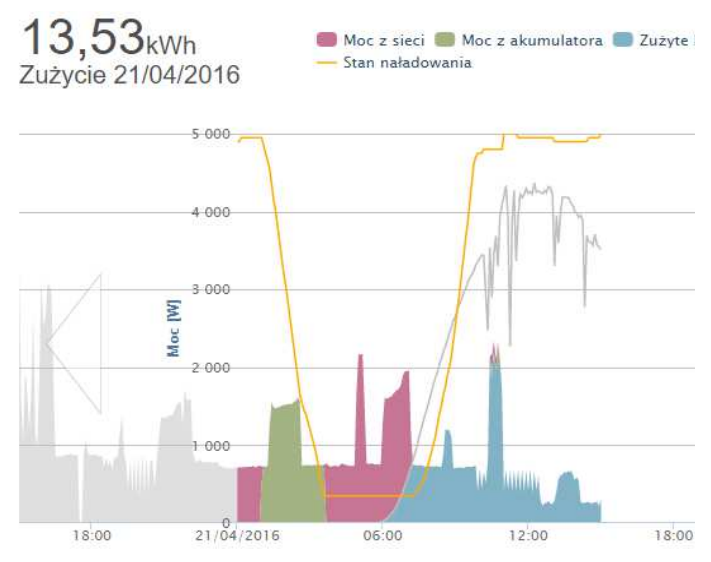

Rys. 8. Przykładowe wyniki pomiarów systemu PV z magazynem energii na WIM UTP w Bydgoszczy, na podstawie $[6,9]$

Fig. 8. Results examples of measurements of system PV with store-house of energy on WIM UTP in Bydgoszcz, based on [6, 9]

Podczas badań starano się uzyskać pełną niezależność energetyczną laboratorium Inżynierii Odnawialnych Źródeł Energii (www.LABIOZE.utp.edu.pl), które jest zasilane przedstawioną w artykule instalacją PV. Odbiornikami zużywającymi ener- 
gię elektryczną w ciągu doby było oświetlenie, komputery oraz instalacje badawczo dydaktyczne, funkcjonujące w laboratorium (pompy ciepła, nagrzewnice itp.).

\section{Wnioski}

Realizacja badań pozwoliła przeanalizować efektywność instalacji PV z magazynem energii w polskich warunkach środowiskowych w wybranym okresie czasu (okres wiosny 2016 roku). Obecne dane z kilku miesięcy są niewystarczające do pełnej oceny przydatności tego typu instalacji. Będą realizowane pełny rok kalendarzowy. Nie mniej jednak pozwalają na optymistyczne założenia, co do potencjału ich wykorzystania. Szczególnie biorąc pod uwagę dane z innych krajów.

Producenci inwerterów fotowoltaicznych zaczynają wprowadzać na rynek dedykowane rozwiązania, które pozwolą na optymalizację autokonsumpcji energii z domowych instalacji PV dzięki możliwości zmagazynowania niewykorzystanych nadwyżek energii i zużycia jej w momencie, gdy odpowiedniej podaży nie zapewnia instalacja fotowoltaiczna. Jeszcze kilka lat temu rozwój rynku domowych instalacji fotowoltaicznych, napędzany był w Europie głównie przez atrakcyjne stawki za sprzedaż energii do sieci. System taki nie tworzył zapotrzebowania na rozwiązania optymalizujące wykorzystanie energii $\mathrm{z}$ domowych instalacji PV na użytek własny ich właścicieli. Ta sytuacja jednak bardzo się zmieniła $[5,6,8]$.

Najlepszym tego przykładem są Niemcy, gdzie w ostatnich latach znacznie zmniejszono stawki sprzedaży energii $\mathrm{z}$ domowych instalacji fotowoltaicznych i gdzie teraz o wiele bardziej opłaca się wykorzystać jej jak najwięcej na własny użytek, oszczędzając na energii niezakupionej od operatora, której koszt jest niemal 3-krotnie wyższy niż stawki sprzedaży energii do sieci [10].

Jedną z ważniejszych wiadomości dla globalnej branży fotowoltaicznej w 2015 r. było rozpoczęcie sprzedaży domowych magazynów energii przez Teslę. Obecnie koszt produktu o nazwie Powerwall to 3 tys. dolarów, jednak imponujące plany Tesli dają nadzieję na obniżenie jego ceny. Rozwój domowych magazynów energii tworzy perspektywiczny rynek dla producentów inwerterów, w zakresie rozwiązań, które będą współpracować z systemami magazynowania energii i dzięki którym będzie możliwa optymalizacja wykorzystania energii z PV na własny użytek. Rozwój w kierunku systemów zakładających magazynowanie energii sygnalizują komunikaty czołowych producentów inwerterów. Firma SMA szacuje wartość globalnego rynku magazynowania energii na około 0,5 mld euro - 1,2 mld euro [10].

\section{Literatura}

[1] Mroziński A.: Poradnik dobrych praktyk wdrażania instalacji odnawialnych źródeł energii. Wydawnictwo 1studio.pl Arkadiusz Bartnik, ISBN 978-83-943206-0-7, Bydgoszcz 2015. 
[2] Kruszelnicka W., Kozłowska N., Mroziński A.: Analiza efektywności energetycznej i ekonomicznej podgrzewania wody użytkowej przez instalację zasilaną modułami fotowoltaicznymi. Mechanik nr 10/2015, str. 70-80.

[3] Mroziński A.: Badanie efektywności energetycznej laboratoryjnej instalacji fotowoltaicznej. Czasopismo Inżynierii Lądowej, Środowiska i Architektury - Journal of Civil Engineering, Environment and Architecture, JCEEA, t. XXXI, z. 61 (3/II/14), 2014, s. 357-366, DOI:10.7862/rb.2014.102.

[4] Szymański B.: Instalacje Fotowoltaiczne. Wydanie II. Wydawnictwo Geosystem Burek, Kotyza s.c., Kraków 2013.

[5] EurObserv'ER, www.eurobserv-er.org, 2016 (dostęp - 15.05.2016 r.).

[6] Materiały techniczne Fronius Symo Hybrid - system Fronius Symo Hybrid 5.0-3-S S24, Fronius Smart Meter oraz Fronius Solar Battery.

[7] http://virtech.pl/fotowoltaika/oferta/falowniki/falowniki-hybrydowe/fronius/722falownik-fronius-symo-hybrid-5-0-3 (dostęp - 15.05.2016 r.).

[8] http://reneweconomy.com.au (dostęp - 15.05.2016 r.).

[9] Własne zdjęcia Autora oraz pomiary z wykorzystaniem monitoringu www.solarweb.com (login: adammroz@utp.edu.pl, hasło: konf999sys).

[10] http://gramwzielone.pl/trendy/20063/producenci-inwerterow-odpowiadaja-narozwoj-magazynow-energii (dostęp - 15.05.2016 r.).

\section{LABORATORY PHOTOVOLTAIC INSTALLATION WITH ENERGY STORAGE}

\section{S u m m a r y}

In the article problem of use in Poland and Europe photovoltaic installation (PV) with storehouses of electric energy was presented. PV systems will be dusts in near future considerable part in global production of electric energy. It will be influenced indeed onto limitation of emission of greenhouses gases as well as onto improvement of state of natural environment. In work building of laboratory PV installation located on WIM UTP in Bydgoszcz was carried out. Choose results of measurements of production schedule and production of electric energy (production by arrangement $\mathrm{PV}$, own use, storing in batteries, dispatch to external net) in time with use of monitoring system were introduced also. In PV installations have big meaning systems of management energy more and more as well as storing arrangements electric energy. Thanks this systems electric produced energy will be day use on currently. Excess of energy will hit to house battery. It will become used evening effectively, when demand onto current is highest. Energy will cover possible shortages from net - bought night or early morning, when price of energy is lowest. Intelligent transmission lines of energy with house installations PV with store-houses of energy will make possible effective management demand and supply of energy in whole energetic system.

Keywords: renewable energy source, efficiency, photovoltaic, energy storages

DOI:10.7862/rb.2016.278

Przestano do redakcji: $30.06 .2016 r$.

Przyjęto do druku: 20.12.2016 r. 